А.О. Романюк ${ }^{1}$, П.Г. Берднік ${ }^{2}$, О.В. Першин ${ }^{1}$, В.М. Павленко ${ }^{2}$

${ }^{1}$ Харківський начіональний університет Повітряних Сил ім. І. Кожедуба, Харків

${ }^{2}$ Харківський наџіональний університет ім. В.Н. Каразіна, Харків

\title{
МЕТОД ПОБУДОВИ МОДЕЛЕЙ ДІЯЛЬНОСТІ БОЙОВИХ ОБСЛУГ АВТОМАТИЗОВАНИХ КОМАНДНИХ ПУНКТІВ ЗА РАХУНОК ОПТИМАЛЬНОГО ПОЄДНАННЯ МЕТОДІВ АНАЛІЗУ І МОДЕЛЮВАННЯ ДІЯЛЬНОСТІ ОПЕРАТОРІВ АВТОМАТИЗОВАНИХ СИСТЕМ УПРАВЛІННЯ
}

3 метою вирішення дослідницьких, інформаційних та тренажних завдань для уніфікації моделей діяльності бойових обслуг, необхідним є врахування вимог наочності і доступності при збереженні можливості проведення аналітичних і експериментальних досліджень. Для визначення ступеня відповідності зазначеним вимогам різних поєднань методів побудови моделей, визначені можливі варіанти групування методів. На основі морфологічного аналізу варіантів поєднань методів моделювання діяльності обслуг автоматизованого командного пункту показано, щзо для комплексного вирімення поставлених завдань раціональним $\epsilon$ доповнення існуючої методики методом структурно-алгоритмічного аналізу та методом узагальнених мережевих моделей діяльності.

Ключові слова: автоматизований командний пункт, бойова обслуга, модель діяльності, метод структурно-алгоритмічного аналізу, метод узагальнених мережевих моделей діяльності.

\section{Вступ}

Постановка проблеми. Підвищення вимог до оперативності та якості вирішення завдань управління обумовлюють необхідність критичного аналізу відомих алгоритмів діяльності бойових обслуг АКП і визначення напрямків їх вдосконалення на етапах розробки, дослідження і застосування для інформаційного забезпечення роботи і навчання.

Для визначення ступеня відповідності зазначеним вимогам необхідним $є$ розгляд оптимальних варіантів групування методів побудови моделей діяльності бойових обслуг автоматизованих командних пунктів.

Аналіз останніх досліджень і публікацій. У [1-2] показано, що з метою розширення можливостей існуючої методики побудови моделей діяльності операторів АСУ ii доцільно доповнити методом структурно-алгоритмічного аналізу (МСА) бойової роботи. Метод структурно-алгоритмічного аналізу дозволяє описати не тільки фізичні дії оператора, а й його психічну (розумову) діяльність, що дає можливість вирішувати питання, які пов'язані з розподілом функцій в системі та проектуванням структури діяльності. До переваг методу відноситься те, що, знаючи характеристики елементарних операцій, можна знайти аналогічні характеристики всього алгоритму в цілому і при необхідності змінити структуру алгоритму за рахунок зміни складу і взаємозв'язків операцій. При цьому МСА не має достатньо розробленої методики вдосконалення сформованої моделі діяльності. Одним з напрямків усунення даного недоліку є доповнення методом мережевих моделей діяльності (МММ).

Метод мережевих моделей діяльності [3] також передбачає розбиття діяльності на ряд елементарних дій, які називаються роботами, а моменти їх завершення - подіями.

Показано [4-5], що від описів на мові МСА можливий перехід до мережевої моделі з використанням апарату PERT або до мережі Петрі.

Опис таких моделей обумовлює використання орієнтовного графу або орграфу. Орієнтованим графом називають сукупність двох множин непорожньої множини вершин і множини орієнтованих ребер (дуг). Кожне ребро з'єднує (зв'язує) упорядковану пару вершин. Кажуть, що дуга зв'язана 3 упорядкованою парою вершин $(u, v)$ починається вершиною $u$ та закінчується у вершині $v$ [6].

Мережі Петрі являють собою математичний апарат для моделювання динамічних дискретних систем. Мережа Петрі є двочастковим орієнтованим графом, що містить вершини двох типів - місця i переходи. Будь-яка дуга веде або від “вершинимісця” в “вершину-перехід”, або навпаки. Дуги, що з'єднують два місця або два переходи, заборонені. Місця, $з$ яких проходить дуга до переходу, називаються вхідними. Місця, до яких ідуть дуги від переходу - вихідними [5].

Часова мережа Петрі характеризується введенням затримок при переміщенні маркера, затримка 
може бути зв'язана як з переходом так і з позицією [5]. Program (Project) Evaluation and Review Technique (скорочено - PERT) - техніка оцінки та аналізу програм (проектів), яка використовується при управлінні проектами. PERT — це спосіб аналізу завдань, необхідних для виконання проекту. Особливо, аналізу часу, який потрібен для виконання кожної окремої задачі, а також визначення мінімального необхідного часу для виконання всього проекту [5]. Діаграма PERT з роботами на стрілках являє собою множину точок-вершин (події) разом $з$ їх з'єднуючими орієнтованими дугами (роботи). Будьякій дузі, що розглядається як якась робота з числа потрібних для здійснення проекту, приписуються визначені кількісні характеристики. Це - обсяги виділених на дану роботу ресурсів і, відповідно, іiі очікувана тривалість (довжина дуги). Будь-яка вершина інтерпретується як подія завершення робіт, представлених дугами, які входять в неї, і одночасно початку робіт, що відображаються дугами, що виходять звідти. Таким чином відображається той факт, що ні до однієї з робіт не можна приступити перш, ніж будуть виконані всі роботи, що передують їй згідно 3 технологією реалізації проекту. Початок цього процесу - вершина без вхідних, а закінчення - вершина без вихідних дуг. Решта вершин повинні мати i ті, й інші дуги [5].

Послідовність дуг, в якій кінець кожної попередньої збігається з початком наступної, трактується як шлях від відправної вершини до завершальної, а сума довжин таких дуг - як його тривалість. Зазвичай початок і кінець реалізації проекту є пов'язані множиною шляхів, довжини яких відрізняються. Найбільша 3 них визначає мінімально можливу (при зафіксованих характеристиках дуг графа) тривалість усього проекту. Відповідний шлях - це критичний шлях, тобто саме від тривалості складових його робіт залежить загальна тривалість проекту, хоча при зміні тривалості будь-яких робіт проекту критичним може стати й інший шлях [5]. При цьому модифіковані часові мережі Петрі рекомендується використовувати для імітаційного моделювання систем підтримки прийняття рішень, а моделі ПЕРТ - для подання та вивчення комплексів взаємопов'язаних робіт і управління ними, що істотно в процесі удосконалення моделі.

Мета статті - розробка методу побудови моделей діяльності бойових обслуг АКП за рахунок оптимального поєднання методів аналізу і моделювання діяльності операторів АСУ.

\section{Виклад основного матеріалу}

\section{Оцінка методу структурно-алгорит- мічного аналізу для побудови моделей бойової роботи обслуг АКП}

У [1-2] показано, що з метою розширення мо- жливостей існуючої методики побудови моделей діяльності операторів АСУ іiі доцільно доповнити методом структурно-алгоритмічного аналізу (МСА) бойової роботи.

В якості недоліків розглянутої моделі слід відмітити відсутність врахування взаємодій операторів i, в зв'язку з цим, застосовність іiі для опису діяльності окремих операторів. Крім того, недостатньо розроблені методи вдосконалення моделі.

Нехай в термінах МСА визначено по узагальнених (типових) ситуаціях, які можуть з'явитися в ході бойової роботи $k$-го оператора 3 певною ймовірністю, і $m$ відповідних їм алгоритмів діяльності (АД). Наявність вирішальних елементів в складі АД передбачає багатоваріантність дій оператора при його реалізації, причому загальне число варіантів алгоритму $n$ можна визначити із співвідношення:

$$
n=\sum_{q=1}^{R} v_{q} u_{q}-\Delta(G),
$$

де $R$ - число типів вирішальних елементів;

$u_{q}$ - число вирішальних елементів $q$-го типу;

$v_{q}$ - число альтернатив у вирішуючого елемента $q$-го типу;

$\Delta(G)$ - скорочення числа випадків через структури АД.

Вибір $j$-го варіанту АД $(j=1,2 \ldots n)$ в $i$-й ситуації $(i=1,2 \ldots m)$ проводиться опера-тором в залежності від поточних умов бойової роботи (поточних ситуацій), які також можуть скластися 3 певною ймовірністю. Таким чином, завдання вирішується оператором по ймовірнісному алгоритму, кожен $j$ й варіант якого здійснюється з імовірністю $P_{i j}$ і являє собою детерміновану послідовність кінцевого числа деяких елементарних операцій.

Тоді, проводячи кодування операції $k$-го оператора в $i$-й ситуації в деякому алфавіті символів, можна побудувати загальний орграф, вершини якого будуть відповідати операціям, а стрілки між вершинами - взаємозв'язкам між операціями. Такому орграфу ізоморфна матриця суміжності $A_{i k}$, число рядків і стовпців якої дорівнює числу операцій, а елементи матриці $a_{p q}$ характеризують частоту проходження операції $q$ безпосередньо за операцією $P$ $\left(a_{p q}=0,1,2 \ldots\right)$. У зв'язку з тим, що зі зміною поточних умов змінюється число необхідних операцій i зв'язки між ними, кожному $j$-му варіанту АД буде відповідати приватний орграф і приватна матриця $A_{i j k}$, число рядків і стовпців якої залежить від заданих поточних ситуацій.

Для побудови структурно-алгоритмічної моделі 
діяльності обслуги АКП в цілому пропонується врахувати сукупність матриць і ізоморфних їм графів $G_{i j k}(A, \Gamma)$, які повинні бути узагальнені в матрицю $D_{i j}$ або в граф $G_{i j}(A, \Gamma)$, які описують діяльність всіх $l$ осіб бойової обслуги. При цьому скористаємося операцією об'єднання графів

$$
\begin{aligned}
& G_{i j}(A, \Gamma) \cup G_{i j 1}\left(A_{1}, \Gamma_{1}\right) \cup \\
& \cup G_{i j 2}\left(A_{2}, \Gamma_{2}\right) \cup \ldots G_{i j}\left(A_{r}, \Gamma_{r}\right) .
\end{aligned}
$$

В даному випадку вершинами графа $G_{i j}(A, \Gamma)$ $\epsilon$ об'єднання операцій осіб бойової обслуги, задіяних в $j$-му варіанті АД.

$$
A=A_{1} \cup A_{2} \cup \ldots A_{r} .
$$

Відображення для кожної вершини графа $G_{i j}(A, \Gamma)$ виходять шляхом об'єднань відображень тієї ж вершини для вихідних графів: $G_{i j 1}\left(A_{1}, \Gamma_{1}\right)$, $G_{i j 2}\left(A_{2}, \Gamma_{2}\right) \ldots G_{i j l}\left(A_{l}, \Gamma_{l}\right)$.

При аналізі моделей діяльності обслуги АКП особливої уваги потребують питання виявлення ролі взаємодій при вирішенні задач в АСУ групою операторів. У відомих джерелах ці питання досліджені недостатньо. Зокрема, розглянуто лише склад мережі комунікацій при взаємодії операторів [8], і особливості різних конфігурацій комунікаційних систем [9]. У той же час саме з наявністю взаємодій головним чином пов'язані втрати часу в результаті очікування команд або донесень і від організації взаємодій багато в чому залежить загальний час вирішення завдань в АСУ. 3 огляду на те, що взаємодії операторів в розглянутих системах відрізняються від інших операцій і полягають в основному в здійсненні узгоджених між операторами і роботою ЕОМ парних операцій (типу “команда - прийом команди”, “донесення - прийом донесення” і т.п. ), пропонується виділити операції взаємодії в загальній матриці суміжності $A_{i j}$. Для цієї мети необхідно групувати в матриці $A_{i j}$ операції кожного $k$-го оператора в порядку їх виконання. Із аналізу елементів такої матриці слідує, що взаємодії повинні задовольняти наступним умовам:

$$
\begin{aligned}
& a_{p q} \neq 0, p_{k}<p<p_{k+1}, q_{k}<q<q_{k+1}, \\
& p \neq 1, q \neq 1, p \neq p_{l}, q \neq q_{l}, k=(\overline{1, l}),
\end{aligned}
$$

де $p_{k}, q_{k}$ - числа операцій, що підлягають виконанню $k$-м оператором.

Завдання вдосконалення АД можна пов'язати 3 виявленням взаємодій, мінімізацією їх числа i, відповідно, зі скороченням числа елементів очікування.

Також не в повній мірі в методі структурноалгоритмічного аналізу розглянуті питання класифікації вхідних ситуацій та їх розпізнавання, хоча від типу ситуації багато в чому залежить характер діяльності операторів і витрати часу на вирішення завдання.

Розглядаючи ситуації на робочих місцях операторів АСУ як сукупність обстановки, процесів іiі розвитку і наслідків [10] при їх класифікації можна використовувати відомі риси, що характеризують середовище - динамічність, невизначеність і складність.

У системотехніці відома процедура розпізнавання ситуації [11], яка містить наступні етапи (рис. 1):

- виділення інформації про ситуацію (про обстановку та процес її розвитку) із загального потоку інформації (блок 1);

- аналіз цієї інформації, поділ її на частини, що відносяться до різних ознаками обстановки і процесу (блок 2);

- визначення ознак, тобто відновлення обстановки і процесу їі розвитку на підставі отриманої інформації (блок 3);

- прогнозування процесу, визначення можливих результатів (блок 4);

- визначення ступеня достовірності прогнозу (блок 5);

- складання опису ситуації (блок 6);

- прийняття інформаційного рішення (блок 7).

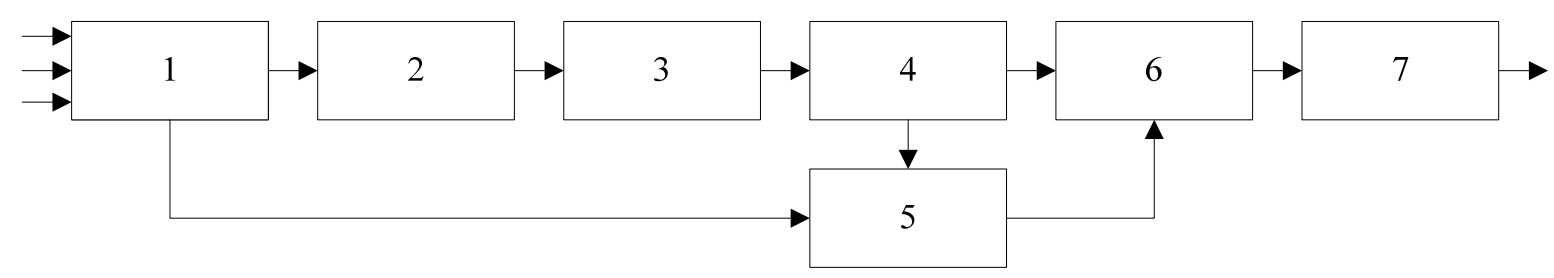

Рис. 1. Відома схема розпізнавання ситуації

Джерело: розроблено авторами за даними [11].

У наведеній процедурі не врахована така особливість діяльності операторів, як можливість творчого підходу при виявленні ситуації і розробці необхідного алгоритму діяльності. Для усунення цього недоліку пропонується включити в схему розпізнавання ситуації ряд додаткових елементів, пов'язаних iз зіставленням ознак ситуації, що склалася з ознаками відомих ситуацій і виявленням нових ситуацій 
(рис. 2).

Додаткові елементи (блоки 7 - 13), які запропоновані для включення в схему розпізнавання ситуації представлені на рис. 2:

блок 7 - зіставлення ознак ситуації, що склалася 3 ознаками відомих ситуацій і виявлення нових ситуацій;

блок 8 - вибір варіанта діяльності певної ситуації;

блок 9 - розробка нового АД в раніше неві- домій ситуації;

блок 10 - розробка нового АД в ситуації, невідомій даному оператору;

блок 11 - застосування (копіювання) відомого АД певної ситуації;

блок 12 - застосування (копіювання) АД для відомої ситуації, розробленої оператором заздалегідь;

блок 13 - розробка нового АД певної ситуації в ході бойової роботи.

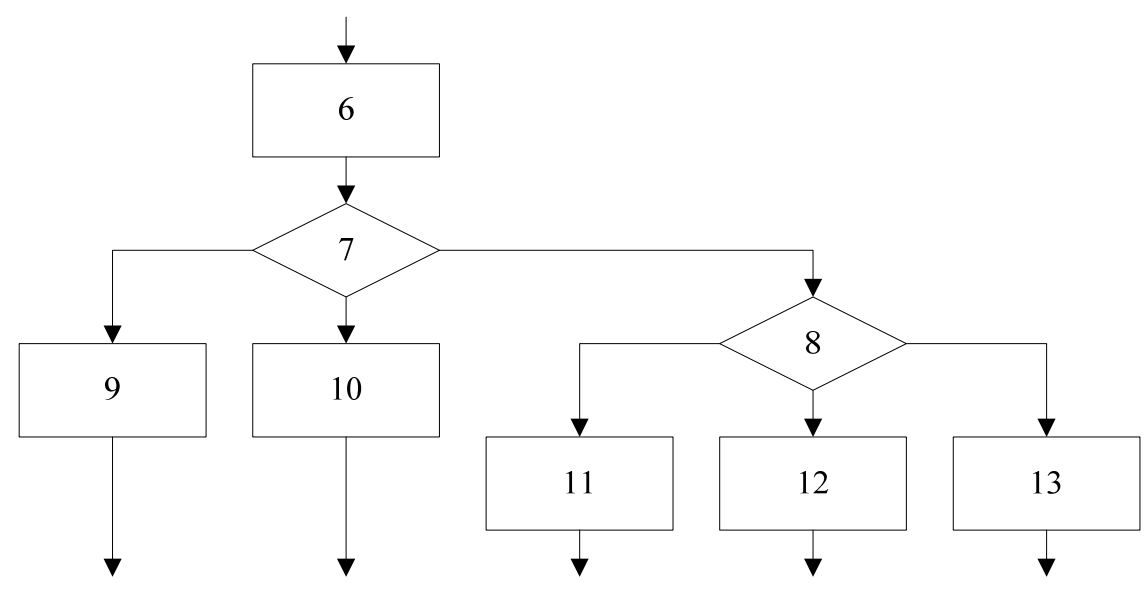

Рис. 2. Додаткові елементи, які запропоновані для включення в схему розпізнавання ситуації Джерело: розроблено авторами.

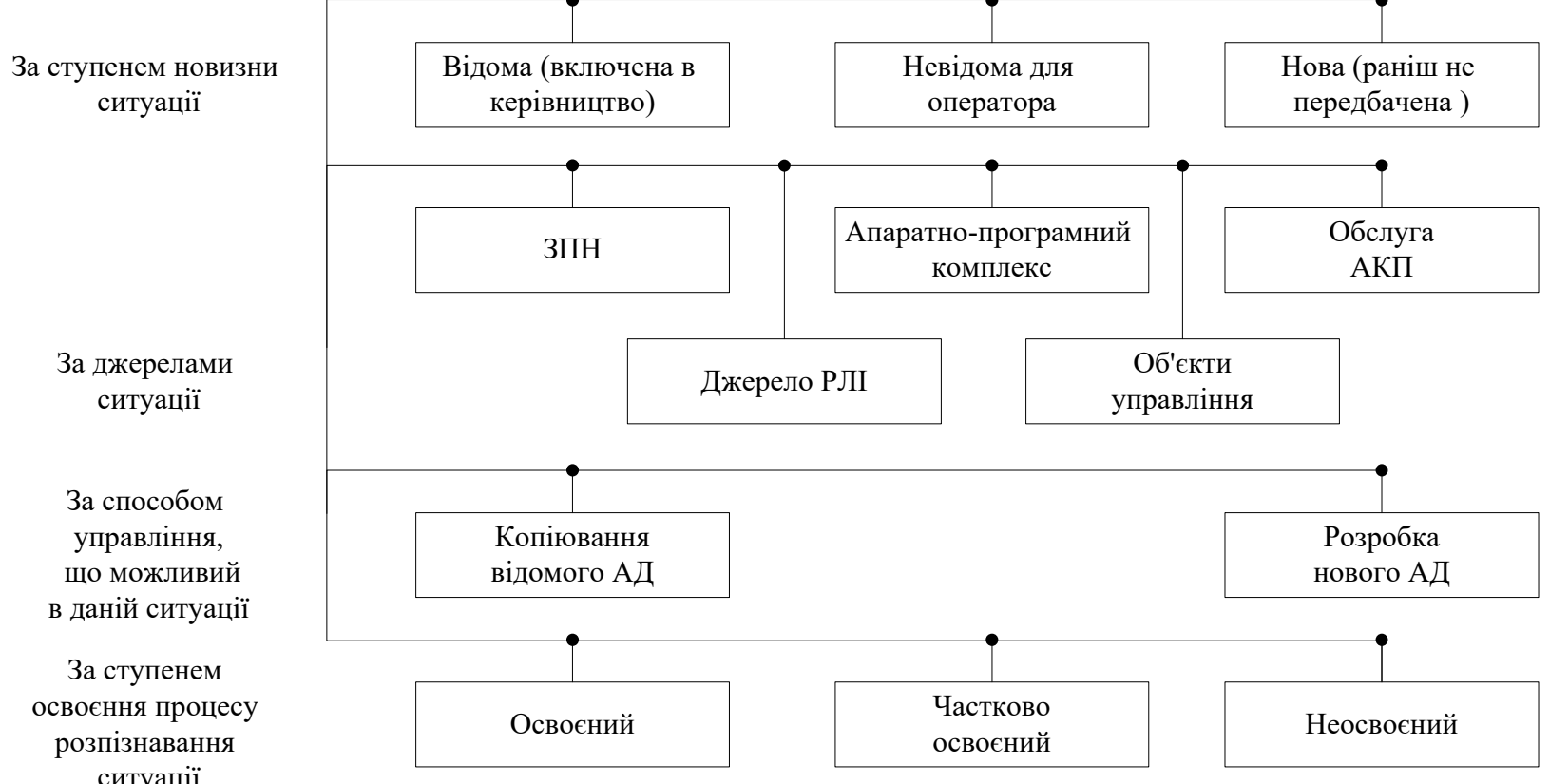

Рис. 3. Варіант класифікації ситуації на робочих місцях операторів АКП для моделей діяльності, уніфікованих для вирішення дослідницьких, інформаційних і тренажних завдань Джерело: розроблено авторами.

Дане доповнення дозволяє ставити задачу пошуку раніше невідомих ситуацій та АД і включення ïx в подальшому в зовнішню пам'ять АСУ, тобто задачу формування перебудовується зовнішньої пам'яті.

При класифікації ініціюючих ситуацій для мо- 
делей діяльності, уніфікованих для вирішення дослідницьких, інформаційних та тренажних завдань, крім ступеня новизни доцільно врахувати джерела ситуації, способи управління, можливі в даній ситуації, і ступінь освоєння процесу розпізнавання ситуацій бойовими обслугами (рис. 3).

Вибір раціональних алгоритмів дій на основі методу мережевих моделей діяльності

Метод структурно-алгоритмічного аналізу не має розробленої методики вдосконалення сформованої моделі діяльності. Одним з напрямків усунен- ня даного недоліку є доповнення МСА методом мережевих моделей діяльності (ММM). Показано [4-5], що від описів на мові МСА можливий перехід до мережевої моделі з використанням апарату ПЕРТ або до мережі Петрі (табл. 1).

При цьому модифіковані часові мережі Петрі рекомендується використовувати для імітаційного моделювання систем підтримки прийняття рішень [4], а моделі ПЕРТ - для подання та вивчення комплексів взаємопов'язаних робіт і управління ними [5], що істотно в процесі удосконалення моделі.

Таблиця 1

Можливості по переходу від описів на мові МCA до моделі ПЕРТ і до мережі Петрі

\begin{tabular}{|c|c|c|c|}
\hline $\begin{array}{c}\text { Найменування } \\
\text { основних блоків }\end{array}$ & $\begin{array}{c}\text { Позначення в } \\
\text { мові МСА }\end{array}$ \\
\hline 1. Початок & Позначення в & Позначення в \\
2. Задача (робота) & моделі Перт & \\
\hline 3. Рішення Петрі
\end{tabular}

Джерело: розроблено авторами.

Але традиційному способу використання МММ властиві такі недоліки [12]:

- неможливість моделювання процесів, що включають роботи 3 неоднозначним результатом, який визначається випадковими чинниками або діями інших систем;

- складність відображення на мережевому графіку альтернативних варіантів досягнення цілей;

- неформальний характер процесу оптимізації мережевого графіка, що базується на досвіді та інтуїції його укладача альтернативні варіанти вирішення завдання.

Але й узагальнена мережева модель діяльності не враховує особливості організації взаємодій опе- раторів в реальному масштабі часу.

Так як для процесу бойової роботи обслуги АКП характерні багатоваріантність і неоднозначність результатів, зазначені недоліки ускладнюють застосування МММ для моделювання діяльності операторів АСУ. Значною мірою подолати недоліки традиційного МММ дозволяє узагальнена мережева модель [13], що припускає введення вирішальних вершин-подій, що дає можливість брати до уваги.

Для розширення можливостей узагальненої мережевої моделі при моделюванні діяльності бойового обслуги пропонується ввести вершини-події “готовність до взаємодії” і “закінчення взаємодії”, які з'єднуються “роботами взаємодії”. При цьому при- 
родною умовою синхронності взаємодії буде рівність критичних шляхів, пов'язаних з попередніми діями взаємодіючих операторів:

$$
\begin{aligned}
& L_{1}^{*}(k)=\max _{L_{1}}\left(\sum_{(i, j) \in L_{1}} t(i, j)\right)= \\
& =L_{2}^{*}(k)=\max \left(\sum_{(m, n) \in L_{2}} t(m, n)\right),
\end{aligned}
$$

де $(i, j),(m, n)$ - роботи першого і другого операторів, що беруть участь у взаємодії;

$t(i, j), t(m, n)$ - тривалість робіт взаємодіючих операторів;

$L_{1}^{*}(k), L_{2}^{*}(k)$ - критичний шлях від вихідної події до $k$-ої події “готовність до взаємодії” для 1го і 2-го операторів відповідно.

Невиконання зазначених умов може призвести до таких наслідків. При напрямку взаємодії від першого оператора до другого (наприклад, перший оператор видає команду, а другий іï приймає і т.п.) в разі $L_{1}^{*}(k)>L_{2}^{*}(k)$ для другого оператора характерні витрати часу на очікування взаємодії, а в разі $L_{1}^{*}(k)<L_{2}^{*}(k)$ в умовах видачі команди операторомкерівником без урахування закінчення дій оператором-виконавцем відбудеться накладення взаємодії на реалізований оператором алгоритм діяльності. У першому випадку з'являються елементи очікування і оператори виявляються нерівномірно завантаженими, у другому випадку можливо неправильне сприйняття команди і зрив виконання задачі.

Для того, щоб домогтися реалізації умови (5) i уникнути зазначених негативних наслідків, необхідно перетворити вихідну мережеву модель. При цьому можуть бути використані наступні прийоми структурних перетворень [14]:

- видалення або додавання дуг і їх переорієнтація (інверсія);

- заміна деякого підграфа однією вершиною (стягування, склеювання поршні);

- видалення підграфа із заміною дуг, що виключають одна другу;

- додавання деякого підграфа або вершини 3 дугами;

- заміна деякої вершини підграфом (розщеплення вершини);

- заміна послідовного виконання робіт паралельним (розчленування великих робіт так, щоб наступні роботи, могли початися після виконання частини розглянутої роботи).

Оцінка критичних шляхів різних варіантів перетворень мережевих моделей може виробляться тільки на основі знання статистичних характеристик тих чи інших робіт - математичного очікування i дисперсії їх тривалості. Так як кожна робота в досліджуваних системах представляє собою сукупність елементарних операцій (перенесення погляду, переміщенні руки, натискання кнопки і т.п.), час її виконання можна розглядати як суму деякого числа незалежних випадкових величин, підпорядкованих нормальному закону розподілу [15]. Але у зв'язку 3 тим, що психофізіологічні можливості людини обмежені, час виконання роботи не може бути менше деякої величини $t_{\min }$. Це призводить до необхідності трансформування розподілу тривалості роботи в усічений знизу нормальний розподіл з параметрами.

$$
\overline{t_{y}}=\sum_{i=1}^{k} t_{i} ; \sigma_{y}^{2}=\sum_{i=1}^{k} \sigma_{i}^{2}
$$

де $k$ - число операцій, що входять до операційного елементу;

$$
t_{i}, \sigma_{i}^{2} \text { - математичне очікування і дисперсія }
$$
тривалості $i$-ї операції.

Функція щільності ймовірності для усіченого нормального розподілу 3 точкою усічення $t_{\min }$ визначається співвідношенням:

$$
f(t)=\left\{\begin{array}{l}
\frac{c}{\sqrt{2 \pi} \sigma_{u}} e^{-\frac{\left(t-t_{u}\right)^{2}}{2 \sigma_{u}^{2}}} \text { при } t>t_{\min ,} \\
0 \quad \text { при } t<t_{\min ,}
\end{array}\right.
$$

де $t_{u}, \sigma_{u}^{2}$ - математичне очікування і дисперсія вихідного нормального розподілу;

\section{$C$ - нормуючий множник.}

Моменти усіченого нормального закону $\overline{t_{y}}$, $\sigma_{y}^{2}$ пов'язані з моментами вихідного закону в такий спосіб (при $t_{\max }=\infty$ ):

$$
\begin{gathered}
\overline{t_{y}}=\overline{t_{u}}+\sigma_{u} B ; \\
\sigma_{y}^{2}=\sigma_{u}\left(1-B^{2}-t \cdot B\right) ; \\
u=\frac{t_{\min }-\overline{t_{u}}}{\sigma_{u}^{2}} ; \\
B_{1}=\frac{C}{\sqrt{2 \pi}} e^{-\frac{u^{2}}{2}}=\frac{1}{\sqrt{2 \pi}\left[0,5-\Phi_{0}(u)\right]} e^{-\frac{u^{2}}{2}},
\end{gathered}
$$

де $\Phi_{0}(u)$ - функція Лапласа-Гаусса.

В результаті рішення наведеної системи рівнянь можуть бути знайдені шукані величини $t_{u}, \sigma_{u}, C$. Однак, так як безпосереднє аналітичне рішення цієї системи рівнянь складне, можна скористатися графічним методом. Для цього визначається параметр:

$$
B_{2}=\frac{\overline{t_{y}}-\overline{t_{u}}}{\sigma_{u}}
$$


Потім графічно будуються функції $B_{1}=f_{1}\left(\overline{t_{u}}\right)$ i $B_{2}=f_{2}\left(\overline{t_{u}}\right)$. Значення $\overline{t_{u}}$, задовольняє рівності $B_{1}=B_{2}$, буде шуканим. Значення $\sigma_{u}$, необхідне для побудови функцій $f_{1}\left(\overline{t_{u}}\right), f_{2}\left(\overline{t_{u}}\right)$ знаходиться із виразу

$$
\sigma_{u}^{2}=\sigma_{y}^{2}+\left(\overline{t_{y}}-\overline{t_{y}}\right)^{2}+\left(t_{\min }-\overline{t_{u}}\right)\left(t_{y}-t_{u}\right) .
$$

Після визначення $\overline{t_{u}}$ і $\sigma_{u}^{2}$ із виразу для $B_{1}$ може бути знайдена величина нормуючого множника $C$ і побудована функція щільності часу виконання роботи операторів.

Функція своєчасності виконання роботи оператором може бути розрахована за наступним вира3ом:

$$
\begin{aligned}
& q(t)=P\left\{t_{\text {on }}<t\right\}=C \int_{t_{\text {min }}}^{t} f\left(t_{u}\right) d t_{u}= \\
& =C\left[\Phi_{0}\left(\frac{\overline{t_{u}}-t_{\min }}{\sigma_{u}}\right)-\Phi_{0}\left(\frac{t-\overline{t_{u}}}{\sigma_{u}}\right)\right] .
\end{aligned}
$$

3 урахуванням розглянутих положень рішення задачі побудови моделі діяльності бойової обслуги АКП пропонується здійснювати в наступному порядку.

1. Вибираються найбільш складні для освоєння фрагменти бойової роботи в типових ситуаціях, пов'язані зі значним числом операційних і вирішальних елементів та які істотно впливають на пропускну здатність АСУ. В якості міри складності діяльності може використовуватися співвідношення (1).

2. На основі описів діяльності окремих операторів, наведених в керівництвах (інструкціях), за відповідними матрицями суміжності і ізоморфних їм графах будується структурно-алгоритмічна модель бойової роботи обслуги АКП в цілому (2).

3. За допомогою аналізу елементів загальної матриці суміжності з урахуванням умов (4) оцінюється характер взаємодій між операторами і будується узагальнена мережева модель діяльності.

4. Оцінюються критичні шляхи до подій “готовність до взаємодії” для різних операторів і з використанням прийомів структурних перетворень мережевих моделей домагаючись виконання умови синхронності дій бойової обслуги (5).

\section{Список літератури}

1. Романюк А.О. Оцінка протиріч в практиці вдосконалення бойової роботи обслуг автоматизованих командних пунктів / А.О. Романюк, І.Г. Дзеверін // Збірник наукових праць Харківського національного університету Повітряних Сил. - 2019. - № 4(62). - С. 74-78. https://doi.org/10.30748/zhups.2019.62.10.

2. Романюк А.О. Аналіз науково-методичного апарату, що застосовується для оцінки і вдосконалення діяльності операторів автоматизованих систем управління / А.О. Романюк, І.Г. Дзеверін // Системи озброєння і військова техніка. - 2019. - № 4(60). - С. 39-46. https://doi.org/10.30748/soivt.2019.60.05.

3. Економіко-математичні методи і прикладні моделі / В.В. Федосєєв, О.М. Гармаш, Д.М. Дайітбегов та ін. - М.:
5. 3 урахуванням накопиченого досвіду бойового застосування АСУ уточнюються витрати часу на виконання операційних і вирішальних елементів і на основі співвідношень (6-14) визначаються показники розподілу тривалості виконання завдання.

\section{Висновки}

В статті представлена розробка методу побудови моделей діяльності бойових обслуг АКП за рахунок оптимального поєднання методів аналізу і моделювання діяльності операторів АСУ.

Проведено оцінку методу структурноалгоритмічного аналізу для побудови моделей бойової роботи обслуг АКП. Пропонується при розгляданні ситуації на робочих місцях операторів АСУ як сукупність обстановки, процесів іiі розвитку і наслідків при їх класифікації можна використовувати відомі риси, що характеризують середовище - динамічність, невизначеність і складність.

Також показано, що етапи відомої процедура розпізнавання ситуації не враховують таку особливість діяльності операторів, як можливість творчого підходу при виявленні ситуації і розробці необхідного алгоритму діяльності.

Для усунення цього недоліку пропонується включити в схему розпізнавання ситуації ряд додаткових елементів, пов'язаних із зіставленням ознак ситуації, що склалася з ознаками відомих ситуацій i виявленням нових ситуацій.

Представлений метода вдосконалення сформованої моделі діяльності операторів АСУ за рахунок доповнення структурно-алгоритмічного аналізу методом мережевих моделей діяльності.

Показано, що традиційному способу використання мережевих моделей діяльності властива низка недоліків. Подолання розглянутих у статті недоліків можливо при застосуванні узагальненої мережевої моделі, яка припускає введення вирішальних вершин-подій “готовність до взаємодії” і “закінчення взаємодії”, які з'єднуються “роботами взаємодії”.

Розроблений порядок дій при рішенні задачі побудови моделі діяльності бойової обслуги автоматизованих командних пунктів. Застосування розробленого методу може дозволити операторам автоматизованих систем управління підвищити оперативність та якість вирішення дослідницьких, інформаційних та тренажних завдань. 
ЮНИТИ, 1999. - 391с.

4. Мараховский В.Б. Моделирование параллельных процессов. Сети Петри / В.Б. Мараховский, Л.Я. Розенблюм,

А.В. Яковлев. - Санкт-Петербург: Профессиональная литература, АйТи-Подготовка, 2014. - 400 с.

5. Лавріщева К.М. Програмна інженерія / К.М. Лавріщева. - К.: Академперіодика, 2008. - 319 с.

6. Компиляторы: принципы, технологии, инструменты / А. Ахо, М. Лам, Р. Сети, Д. Ульман. - М.: Вильямс, 2008. - 184 с.

8. Соломонов Л.А. Персональные автоматизированные информационные системы и дисплейные комплексы /

Л.А. Соломонов, Ю.Н. Филлипович, В.Л. Шульгин. - М.: Высш. школа, 1990. - 143 с.

9. Мунипов В.М. Эргономика / В.М. Мунипов, В.П. Зинченко. - М.: Логос, 2001. -356 с.

10. Шестакова Л.А. Методологические и инженерно-психологические параметры функционирования современных социально-технических систем / Л.А. Шестакова // Вестник Национального Государственного Технического Университета им. Р.Е. Алексеева. - 2013. - № 2. - С. 40-47.

11. Основи творення машин / М.Я. Бучинський, О.В. Горик, А.М. Чернявський, С.В. Яхін. - Х.: НТМТ, 2017. - 448 с.

12. Холл А. Опыт методологии для системотехники / А. Холл. - М.: Знание, 1975. -419 с.

13. Кофман А. Сетевые методы планирования и их применение / А. Кофман, Г. Дебазей. - М.: Прогресс, 1968. - 182 c.

14. Белкин А.Р. Принятие решений: комбинаторные модели аппроксимации информации / А.Р. Белкин, М.Ш. Левин. - М.: Высш. школа, 1990. - 156 с.

15. Вентцель Е.С. Теория вероятностей / Е.С. Вентцель. - М.: Юстиция, 2018. - 658 с.

Надійшла до редколегії 06.01.2021

Схвалена до друку 09.02.2021

Відомості про авторів:

Романюк Алла Олександрівна

науковий співробітник

Харківського національного університету

Повітряних Сил ім. І. Кожедуба,

Харків, Україна

https://orcid.org/0000-0001-5882-6962

Берднік Поліна Геннадіївна

кандидат технічних наук доцент

Харківського національного

університету ім. В.Н. Каразіна,

Харків, Україна

https://orcid.org/0000-0002-4022-5664

\section{Першин Олександр Васильович}

викладач

Харківського національного університету

Повітряних Сил ім. І. Кожедуба,

Харків, Україна

https://orcid.org/0000-0003-0022-8972

\section{Павленко Владислава Максимівна}

студентка

Харківського національного

університету ім. В.Н. Каразіна,

Харків, Україна

https://orcid.org/0000-0003-0976-0252

\section{Information about the authors:}

\author{
Alla Romaniuk \\ Research Associate \\ of Ivan Kozhedub Kharkiv \\ National Air Force University, \\ Kharkiv, Ukraine \\ https://orcid.org/0000-0001-5882-6962 \\ Polina Berdnik \\ Candidate of Technical Sciences Senior Lecturer \\ of Karazin Kharkiv \\ National University, \\ Kharkiv, Ukraine \\ https://orcid.org/0000-0002-4022-5664
}

\author{
Alexander Pershin \\ Instructor \\ of Ivan Kozhedub Kharkiv \\ National Air Force University, \\ Kharkiv, Ukraine \\ http://orcid.org/0000-0003-0022-8972
}

\author{
Vladyslava Pavlenko \\ Student \\ of Karazin Kharkiv \\ National University, \\ Kharkiv, Ukraine \\ https://orcid.org/0000-0003-0976-0252
}

\section{МЕТОД ПОСТРОЕНИЯ МОДЕЛЕЙ ДЕЯТЕЛЬНОСТИ БОЕВОГО РАСЧЕТА АВТОМАТИЗИРОВАННЫХ КОМАНДНЫХ ПУНКТОВ ЗА СЧЕТ ОПТИМАЛЬНОГО СОЧЕТАНИЯ МЕТОДОВ АНАЛИЗА И МОДЕЛИРОВАНИЯ ДЕЯТЕЛЬНОСТИ ОПЕРАТОРОВ АВТОМАТИЗИРОВАННЫХ СИСТЕМ УПРАВЛЕНИЯ}

А.А. Романюк, П.Г. Бердник, А.В. Першин, В.М. Павленко

С иелью решения исследовательских, информационных и тренажерных задач для унификации моделей деятельности боевых расчетов, необходимо учитывать требования наглядности и доступности при сохранении возможности проведения аналитических и экспериментальных исследований. Для определения степени соответствия указанным требованиям различных сочетаний методов построения моделей определены возможные варианты группировки методов. На основе морфологического анализа различных вариантов сочетаний методов моделирования деятельности расчетов АКП показано, что для комплексного решения поставленных задач рациональным является дополнение сущест- 
вующей методики методом структурно-алгоритмического анализа и методом обобщенных сетевых моделей деятельности.

Ключевые слова: автоматизированный командный пункт, боевой расчет, модель деятельности, метод структурно-алгоритмического анализа, метод обобщенных сетевых моделей деятельности.

\section{METHOD FOR CONSTRUCTING MODELS OF BATTLE CALCULATION OF AUTOMATED COMMAND POINTS DUE TO OPTIMAL COMBINATION OF METHODS FOR ANALYSIS AND SIMULATION OF OPERATORS OF AUTOMATED CONTROL SYSTEMS}

A. Romaniuk, P. Berdnik, A. Pershin, V. Pavlenko

In order to solve research, information and training tasks for the unification of models of the activity of combat crews, it is necessary to take into account the requirements of visibility and accessibility while maintaining the possibility of conducting analytical and experimental research. To determine the degree of compliance with the specified requirements of various combinations of methods for constructing models, possible options for grouping methods have been identified. The article presents a roster of the method of motivating the models of the efficiency of the combat servants of the automatic control system for the development of optimal methods for analyzing and modeling the efficiency of the operators in the ACS. The assessment of the method of structural-algorithmic analysis was carried out to induce models of combat robots of the ACP service personnel. It is understood when looking at the situation on the work platforms of the operators in the automated control system, as the situation, the processes of development and inheritance in the course of these classifications can be victorious, because of the lack of rice, which characterizes the middle of the warehouse. It has also been shown that the stage of a given procedure for identifying a situation does not provide for such a special function of the operators, as the possibility of a creative approach in the event of a situation and the development of the necessary algorithm of action. For usunenny a o a shortcoming, it is suggested to include in the scheme of identifying a situation a number of additional elements, connected from the left to the sign of the situation, which was expressed as signs of new situations and new situations. Presentations of the method for a thoroughly formed model of the activity of operators in the automated control system for the improvement of the structural-algorithmic analysis by the method of fingered models of activity. It is shown that the traditional method of victorious patterned models has low power levels. Some of the shortcomings in the statistic are possible with the stagnation of the global low-cut model, as the allowance is made for the introduction of viral peaks-podias "readiness for interchange" and "end of the process", as a result of. The order of breaking up is done when solving tasks to induce models of the activity of the combat service of the AKP. The stagnation of the broken-down method can allow the operators of the automated control system to adjust the efficiency and the quality of the distribution of the facilities at the earlier, information and training facilities.

Keywords: automated command post, combat crew, activity model, method of structural and algorithmic analysis, method of generalized network models of activity. 